DOI

\title{
ЗМІНИ ГУМОРАЛЬНОГО ІМУНІТЕТУ ПРИ ПОРУШЕННІ МЕНСТРУАЛЬНОГО ЦИКЛУ У ЖІНОК, ЩО ХВОРІЮТЬ НА ТУБЕРКУЛЬОЗ
}

\author{
๑С. П. Польова, О. В. Романюк
}

Ковельський медичний коледж

\begin{abstract}
РЕЗЮМЕ. Наведені результати досліджень стану гуморальної ланки імунітету у пацієнток з порушеннями менструального циклу, що хворіють на туберкульоз легень. Показано, що менструальний цикл у даної когорти жінок зазнає суттєвих порушень в результаті зниження функціональної здатності В-лімфоцитів, незважаючи на компенсаторне збільшення їх відносної кількості та функціональної здатності і продукції імуноглобулінів основних класів.

КЛЮчОВІ СлОВА: туберкульоз, менструальний цикл, гуморальний імунітет, діагностика.
\end{abstract}

Вступ. Менструальна функція за наявності туберкульозу (ТБ) легень у жінок зазнає різноманітних порушень у 72,3 \% осіб. Нерегулярний менструальний цикл (МЦ) трапляється у 36,8 \% осіб, альгодисменорея - у 30,0 \%, гіперполіменорея -у 26,8 \% жінок, проліферативні зміни ендометрія у 28,9\%, кісти і новоутворення яєчників трапляються у 24,7 \% випадків, первинна та вторинна аменорея - у 8,1 \% випадків тощо. За поширених і поєднаних форм ТБ частка дисменореї та менорагії удвічі вища, порівняно з вогнищевим ураженням легеневої тканини $[1,3,4,6]$.

У комплексі захисних реакцій за наявності ТБ, суттєва роль належить специфічній гуморальній ланці імунітету, проте остання досліджена недостатньо, зважаючи, що антитіла до мікобактеріальних антигенів циркулюють у крові за наявності будь-якої форми ТБ, а імунна відповідь на антитіла складна і залежить від багатьох чинників $[2,4,9]$. Достатньо значима цитокінпродукувальна активність В-лімфоцитів за наявності ВДТБ, здатність активованих В-лімфоцитів продукувати такі медіатори, як ІЛ-1, ІЛ-4, ІЛ-6, ІЛ-12, ФНО- $\alpha$ та ін., роль яких зростає при патологічних станах репродуктивної системи $[2,7,8]$. Все це вимагає визначити механізми впливу ендогенної інтоксикації на менструальну функцію, репродуктивні органи, реактивність організму, гормональну та ендокринну системи у пацієнток, що хворіють на туберкульоз легень $[4,5,6]$.

Мета. Визначити показники гуморальної ланки імунітету при порушенні менструальної функції у жінок, що хворіють на туберкульоз легень.

Матеріал і методи дослідження. Проведено обстеження 48 пацієнток репродуктивного віку, що хворіють на туберкульоз легень (основна група) та 30 здорових жінок (контрольна група).

Цільну кров досліджували на гематологічному аналізаторі «Ce1trak-11» фірми «Ваег» (Австрія). Субпопуляції В-лімфоцитів проводили у реакції імунофлуоресценції з моноклональними антитілами (фірми «Сорбент-лТД», Москва). Рівень імуноглобулінів основних класів (IgM, IgG, IgA) у сироватці крові визначали методом радіальної імунодифузії в агарі (реакція преципітації за Манчіні) із застосуванням дослідної сироватки, агару "Difco", медіналового буфера та стандартних моноспецифічних антисироваток проти імуноглобулінів класів $M, G, A$, які розводили дистильованою водою.

Результати й обговорення. У жінок, які хворіють на ТБ легень, визначали зміни показників гуморальної ланки системного імунітету I, II, та III ступенів імунних порушень, які виявлені однаково часто (табл. 1). Зростала відносна кількість В-лімфоцитів (CD ${ }^{20+}$ ) на 46,5 \%, проте загальна функціональна їх здатність щодо синтезу та продукції імуноглобулінів основних класів знизилася на 5,6 \%. Зниження на 33,2 \% рівня Ig G, який виконує основну захисну роль у протиінфекційному захисті і має прогностичну значимість, негативно відображалося на перебігу МЦ. Концентрація IgM зростала на 53,8 \%, a IgA - на 81,4 \%, що підтверджує нове поступання антигенів у кров'яне русло.

у здорових жінок відносна кількість В-лімфоцитів (CD $20+$ клітин) зменшувалася на $17,0 \%$, спостерігалася тенденція до зростання лейкоцитарного В-клітинного індексу та знижувався рівень сироваткового IgA на 6,4 \%. Концентрація IgM та IgG також мала тенденцію до зростання. У пацієнток контрольної групи ступінь імунних порушень не виходив за межі першого рівня.

Комплексна оцінка досліджуваних показників імунного гомеостазу з врахуванням гормонального гомеостазу жінок впродовж МЦ засвідчила, що системний імунітет $\epsilon$ нестійким, його ланки працюють у напруженому режимі, що відображається на порушенні МЦ. 
Огляди літератури, оригінальні дослідження, погляд на проблему

Таблиця 1. Показники гуморальної ланки системного імунітету у жінок, що хворіють на туберкульоз легень

\begin{tabular}{|c|c|c|c|c|c|c|}
\hline \multirow[b]{2}{*}{ Показники } & \multirow{2}{*}{$\begin{array}{l}\text { Одиниці } \\
\text { виміру }\end{array}$} & \multicolumn{2}{|c|}{$\begin{array}{c}\text { Основна група } \\
(n=48)\end{array}$} & \multicolumn{2}{|c|}{$\begin{array}{c}\text { Контрольна група } \\
(n=30)\end{array}$} & \multirow[b]{2}{*}{$P$} \\
\hline & & $\begin{array}{c}\text { пацієнтки, хворі на } \\
\text { туберкульоз легень } \\
(\mathrm{M \pm m})\end{array}$ & $\mathrm{CI}$ & $\begin{array}{c}\text { здорові жінки }(\mathrm{n}=32) \\
(\mathrm{M} \pm \mathrm{m})\end{array}$ & $\mathrm{CI}$ & \\
\hline В-лімфоцити $\left(\mathrm{CD}^{20+}\right)$ & $\%$ & $18,52 \pm 1,23$ & II & $12,64 \pm 1,17$ & $\mathrm{I}$ & $<0,01$ \\
\hline $\begin{array}{l}\text { Лейко-В-клітинний } \\
\text { індекс }\end{array}$ & од. & $0,42 \pm 0,05$ & $\mathrm{I}$ & $0,53 \pm 0,05$ & $\mathrm{I}$ & $<0,05$ \\
\hline \begin{tabular}{|l} 
Концентрація \\
імуноглобулінів
\end{tabular} & г/л & $15,44 \pm 0,37$ & I & $16,31 \pm 0,46$ & 1 & $<0,05$ \\
\hline $\lg M$ & г/л & $2,77 \pm 0,18$ & III & $1,32 \pm 0,17$ & II & $<0,05$ \\
\hline IgG & г/л & $10,13 \pm 0,63$ & II & $13,50 \pm 0,88$ & 1 & $<0,05$ \\
\hline IgA & г/л & $2,54 \pm 029$ & III & $1,49 \pm 0,34$ & 1 & $<0,05$ \\
\hline
\end{tabular}

Примітки:

1. СІП- ступінь імунних порушень;

2. P - порівняння показників жінок основної групи з показниками здорових жінок.

Результати досліджень показали, що характер перебігу ТБ та ступінь туберкульозної інток- сикації негативно впливають на стан гіпоталамогіпофізарно-яєчникової системи (табл. 2).

Таблиця 2. Гормональний гомеостаз пацієнток, хворих на туберкульоз легень

\begin{tabular}{|c|c|c|}
\hline Гормони & Основна група ( $\mathrm{n}=25)$ & Контролна група $(\mathrm{n}=20)$ \\
\hline ФСГ (МО/мл) & $13,2 \pm 1,21$ & $9,6 \pm 1,12$ \\
\hline ЛГ (МО/мл) & $12,5 \pm 1,1$ & $8,5 \pm 1,3$ \\
\hline Е (Пг/мл) & $98,3 \pm 6,2$ & $76,3 \pm 4,1$ \\
\hline Пг (нмоль/л) & $21,4 \pm 3,4$ & $16,9 \pm 2,7$ \\
\hline
\end{tabular}

За результатами визначення імуногормонального гомеостазу встановлено тенденцію щодо порушень менструальної функції у жінок, залежно від форми туберкульозного ураження.

Пацієнтки, хворі на дисемінований туберкульоз легень, схильні до гіперполіменорей на тлі абсолютної та відносної естрогенії, з недостатністю лютеїнової фази МЦ та ускладненим паритетом. У жінок, що хворіють на фібрознокавернозний туберкульоз легень, порушення МЦ відбуваються за типом альгодисменореї, часто мають місце ановуляторні цикли, визначається абсолютна або відносна естрогенія та недостат-

\section{ЛІТЕРАТУРА}

1. Гарбузюк В. В. Порушення репродуктивної функції у жінок, хворих на туберкульоз легень / В. В. Гарбузюк, С. П. Польова, Н. В. Корандо // Лікарська справа. Врачебное дело.- 2014. - № 7-8 (1129). - С. 73-75.

2. К вопросу о патологии иммунитета при туберкулезе легких / В. В. Новицкий, О. В. Воронкова, О. И. Уразова [и др.] // Патологическая физиология и экспериментальная терапия. - 2008. - № 1. - С. 15-18.

3. Тодоріко Л. Д. Сучасні аспекти перебігу туберкульозу легень у жінок / Л. Д. Тодоріко// Клінічна іму- ність лютеїнової фази. Вогнищевий туберкульоз легень без ознак інтоксикації не сприяє порушенням МЦ у жінок. У цих пацієнток переважно спостерігають недостатність лютеїнової фази, відносна естрогенія тощо.

Висновок. Менструальний цикл у пацієнток, хворих на туберкульоз легень, перебігає на тлі імунодефіцитного стану гуморальної ланки, ступінь проявів якої визначає рівень інтоксикації.

Перспективи подальших досліджень. У наступних дослідженнях будуть вивчені показники цитокінів при порушенні меструальної функції у жінок, що хворіють на туберкульоз легень. 
Огляди літератури, оригінальні дослідження, погляд на проблему

зом / М. Н. Щербань, Е. В. Кульчавеня, Е. В. Брижатюк

[и др.] // Проблемы туберкулеза и болезней легких. 2008. - № 9. - С. 3-6.

7. Федорова Г. В. Медико-социальные аспекты туберкулеза мочеполовой системы на территории Омской области / Г. В. Федорова, В. В. Леонтьев // Здравоохранение Российской Федерации. - 2007. - №1. - С. 27-29.
8. Фещенко Ю. І. Організація контролю за хіміорезистентним туберкульозом в Україні / Ю.І. Фещенко, В. М. Мельник. К. : Здоров'я, 2013. - 703 с.

9. Чернушенко К. Ф. Імунологічні методи у діагностиці туберкульозу / К. Ф. Чернушенко // Лабораторна діагностика. - 2005. - № 2 (32). - С. 61-66.

\title{
CHANGES OF HUMORAL IMMUNITY UNDER MENSTRUAL CYCLE DISORDERS IN WOMEN WITH TUBERCULOSIS
}

\author{
@S. P. Polyova, O. V. Romaniuk
}

\section{Kovel Medical College}

SUMMARY. Research results of humoral immunity state in patients with menstrual irregularities, suffering from tuberculosis are presented. It is shown that the menstrual cycle (MC) in a cohort of women undergoes significant violations by reducing the functional ability of B-lymphocytes ( $\left.C D^{20+}\right)$ by $46.5 \%$, despite a compensatory increase in their relative amount, functional capacity and reduction of production of major classes of immunoglobulins by $5.6 \%$. It is proved that IgG lowering by $33.2 \%$ has a predictive value and negative impact on the flow of MC. Rising concentrations of IgM by $53.8 \%$ and IgA by $81.4 \%$ confirmed new revenue of antigens into the bloodstream.

KEY WORDS: tuberculosis, menstrual cycle, humoral immunity, diagnosis. 